\title{
Kepolisemian Verba Tsukerus: Kajian Linguistik Kognitif
}

\author{
Prisyanti Suciaty ${ }^{{ }^{*}}$, Dedi Sutedi ${ }^{2}$ Herniwati $^{3}$ \\ ${ }^{1}$ Universitas Negeri Padang, Indonesia \\ Jl. Prof. Hamka, Air Tawar, 25131, Padang, Indonesia \\ 2,3 Departemen Pendidikan Bahasa Jepang, Universitas Pendidikan Indonesia \\ Jl. Dr. Setiabudhi No. 229, Bandung, Indonesia \\ *e-mail : prisyanti.suciaty@gmail.com \\ phone: +62-852-6444-6550
}

\begin{abstract}
Abstrak
Polisemi merupakan salah satu tema yang dibahas ketika berbicara mengenai makna sebuah kata. Kata yang berpolisemi adalah kata yang memiliki makna lebih dari satu. Penelitian ini meneliti makna verba tsukeru yang berpolisemi. Verba tsukeru dianalisis dengan menggunakan kajian linguistik kognitif. Tujuan dari penelitian ini untuk mendeskripsikan makna dasar, mengklasifiksikan makna perluasan, serta mendeskripsikan hubungan antara makna dasar dan makna perluasan dari verba tsukeru. Metode yang dilakukan dalam penelitian ini adalah metode deskriptif. Data yang digunakan yaitu jitsurei yang diperoleh dari korpus BCCWJ (Balanced Corpus of Contemporary Written Japanese) yang bersumber dari dokumen, majalah, koran, buku pelajarann, buletin, dan yahoo yang terbit antara tahun 2000-2008. Selanjutnya dicatat dalam bentuk kartu data. Kemudian dilanjutkan dengan mengklasifikasikan data ke dalam makna dasar dan makna perluasan,dan menganalisis hubungan makna dasar dan makna perluasan menggunakan kajian linguistik kognitif yakni menurut majas metafora, metonimi, dan sinekdoke. Hasil penelitian yang ditemukan adalah verba tsukeru memiliki makna dasar memasang. Kemudian ditemukan 15 makna perluasan yaitu memberi, menempatkan, menambahkan, merendam, mencampurkan, menyalakan, mengoles, mengawasi yang masuk kepada perluasan metafora, selanjutnya menetapkan, mempekerjakan, dan menulis masuk ke peluasan metonimi, terakhir menggores, mengenakan, dan menghentikan perluasan makna sinekdoke. Selain itu ditemukan juga makna idiomatikal seperti membatasi, terbiasa, bertengkar, menuduh, lepas tangan, berhati-hati, memandang, mengerjakan, dan melengkapi diri.
\end{abstract}

\section{Kata Kunci: Polisemi; Verba; Semantik; Linguistik Kognitif}

\begin{abstract}
This paper present an analysis of tsukeru verb which have multiple meanings and in which the mulitple meanings of a word may be connected or related. While this analysis based on cognitive linguistics. The goal of this analysis is describe basic meaning and another meanings of tsukeru verb, and also describe relation of basic meaning and another meanings, and the last present meanings structure of tsukeru verb. The analysis using data form Balanced Corpus of Chunagon contemporary Written Japanese corpus presented by National Institute for Japanese Language and Linguistics. Sentence data in this paper based on document, magazine, newspaper, study books, bulletin, and yahoo at 2000-2008. This data clasification using data card (table data). Decription of relation basic meaning and another meanings using cognitive linguistics analysis which is metaphor, metonymy, and synecdoche. The result of this research is tsukeru verb have basic meaning is put on, and then founded 15 another meanings. Result are follow including metaphor are give, put, adding, soaking, mix, ignite, spreading, watching, including metonymy are decide, hiring, writing, and the last is including synecdoche are slash, dress, stop.
\end{abstract}


Furthermore, fouded idiom meanings such as define, common, quarrel, accuse, hands off, be careful, starring at, doing, acquire.

\section{Keywords: Polysemy; Verb; Semantics; Cognitive Linguistics}

\section{はじめに}

本稿では、多くな意味が用いる動詞 「つける」の分析を行う。意味分析と いえば類義語と多義語という意味があ る。類義語は語形が異なり、意味が良 く似ている、多義語は一つの語が複数 な意味を持っている。同音異義も複数 な意味があるが、語と語はもともと別 の語で、意味の間に関連性がまったく ない。けれども、多義語では、意味の 間に関連性がある。

動詞「つける」の意味は以下のように 見られる。

（1）空にカーテンを付ける。（小泉, 1996: 324)

（2）元気を付ける。（松浦，2005: 1114)

（3）首相に頑健な男たちを護衛として 付ける。（小泉，1996：325）

（4）勝負を付ける。（小泉，1996：325）

（5）日記をつける。（野間， 1989： 1431)

（6）重要人物に護衛を付ける。（小泉, 1996: 325)

（7）先生は生徒たちを席に着けた。（小 泉，1996：326)
（8）船頭は船を岸に着けた。（小泉, 1996: 326)

（9）機長は制服を身に着けた。（小泉， 1996: 326)

（10）顔にクリームをつける。（松浦, 2005：1115)

(11) 刑事につけられる。（松浦，2005： 1114)

（12）足を大地に付ける。（小泉，1996： 324)

（13）子供がレコード傷を付けた。（小泉， 1996: 324)

（14）足を水につける。（松浦，2005： 1114)

(15)テレビをつける。（野間，1989: 1431)

（16）食品に塩をまぶしをつける。（野間, 1989: 1431)

上記の意味を見ると、動詞「つける」 は複数な意味があり、またはそれらの 意味が関連性を見られているため、多 義語であることがわかる。

日本語母語話者なら、これらの意味が 直感で使い分けられるが、非日本語母 語話者だったら、知識がないと使い分 けられない。その知識を得るために、 
辞書や教科書が必要である。けれども、 現代インドネシアでは十分な考察がな されていないと思われる。例えば、イ ンドネシアでよく使われている辞書に は（5）と（8）の意味が取り上げてな いさらに、中級までの教科書にもく

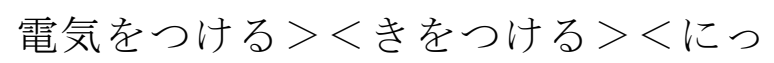
きをつける>しか掲載されていない。 となると、説明不足で学習する場合は 学者や教師が困難や使いこなせないこ とを避けられないと思われる。 そのため、本研究では、意味を一つ以 上持つ言葉の一つである動詞「つける」 の基本義と別儀を記述し、さらにそれ らの意味の関連性を明らかにすること を目的とする。その関連性を分析する 基準は別儀が見られ、そこにかならず 理由があるという認知言語論において 記述する。認知言語学論ではメタファ 一、メタオニミー、シネクドケ、三つ の慣用句に基づいて意味の関連性が見 られる。このように、さまざまな「つ ける」の意味の相互の関連を明らかに して、詳細に意味を捉え、「つける」 の特徵も見られることが可能となる。 「つける」の意味がどのような関連性 があるのかを理解できたら、学習者の 誤用が減られるだろう。
以下では、まず 2 節において「つける」 の意味を記述している先行研究を取り 上げ、検討する。3 節では、基本義と別 儀を記述定義を試み、または基本義と 転義どのような関連性が用いられるの か、さらに現代日本語書き言葉均衡コ 一パス通常版からの実例も加えて分析 を行う。4 節では、本研究のまとめとし て、「つける」の多義語を認知的な定 義を記述する。

\section{先行研究}

本研究では、辞書類と鈴木（2000）か か らの意味記述を取り上げ、その記述内 容を検討する。

\section{辞書の記述}

ここでは、小泉（1989）の日本語基 本動詞用法辞典・インドネシアで多く 利用され、学習者向けの松浦（2005）

の Jepang-Indonesia 大辞典 - 佐和子 （1989）の日本語大辞典第二版の意味 記述を取り上げる。

そのまえに、以下に「つける」の漢 字が異なると見られてるが、国広 （1994）によると、同じ音がする語で、 漢字が違っても、意味が異なると限ら ないということを述べている。

『日本語基本動詞用法辞典』（小泉）

ア.つける「付ける」 
（1）二つの物を合わせて離れない 状態にする。

（2）ある物・事に別の物・事を （新たに）加える。

（3）人をある人のそばを離れない ようにさせる。

（4）事柄をある状態に落ち着かせ る。

（5）ノートなどに書き込む。

（6）人・動物・車などの後をひそ かに追う。

（7）名前を与える。

イ。つける「着ける」

（1）衣服・装身具などを装う。

（2）乗り物をある場所に止める、 降りられるようにする。

（3）ある場所を占めさせる。

（4）手・足・頭などをある場所に 触れさせる

ウ。つける「点ける」

（1）火を燃やし始める。

（2）電気器具 - 点火器具 - 然焼器 具のスイッチを入れて働かせ る。

上記に取り上げている意味から見ると、 「つける」の意味が三つ分かられてい るということがわかる。または、その
三つの意味の中にも様々な意味を持っ ている。

『Kamus Besar Bahasa Jepang-Indonesia』 (松浦)

1.つける

2. ぬる

3.つける、きる

4. つける, ともす

5.つける、

6. つける

7.おう

8.はる

9、あたえる。

上記に取り上げている意味から見ると、 「つける」の意味が九つ分かられてい る。多くの意味があるため「つける」 は多義語であることがわかる。という ことがわかるが、記述した意味が不十 分ではないと思われる。それは、「書 く」<日記をつける $>$ と「決める」< 決着をつけるという意味がまだ取り上 げられていないことである。

『日本語大辞典 第二版』（野間佐和 子・講談社)

ア.つける「付ける」

（1）色・においなど異質なものを 付ける着させる。くつつける。 
（2）二つものを接合して離れない 状態にする。

(3) 新たにべつのものそえる。

（4）あるものに付随的なものをそ える。

（5）物の表面などにあと残す。

（6）人・車などのあとを追う。尾 行する。

（7）書き留める。書き記す。

（8）道・電話などが通じるように する。

（9）注意をする。意識を働かせる。

（10）結論を出す。決める。

（11）名前・評価などを与える。

（12）付き添える。

（13）知恵・技術・能力などを新た に加えて、より価值を上げる。

（14）自分のほうへ荷担させる。

イ・つける「即ける」

（1）君主の位に上らせる

ウ。つける「点ける」

（1）電気製品のスイッチを入れ る。点す。火を燃やし始め る。

（2）火を然やしはじめる。
（1）従うようにさせる。兄弟に する。

（2）任じる。地位や役にすえる。 オ.つける「着ける」

（1）乗り物などを移動してある 場所に着くようにする。

（2）衣服・装身具などを身にま とう。

（3）位置を占めさせる。すらわ あせる。

カ.つける「浸ける」

（1）水などの液体にひたす。

\section{キ.つける「漬ける」}

（1）食品を塩をまぶしたり、み そなどの中に入れて、味を 染み込ませる。漬物にする。

\section{ク.つける「付ける」}

（1）その物事を他に与える意を 表す。

『日本語大辞典 第二版』のア (1) と (5) の意味は同じく表面に色・においなど 異質なものを付ける着させるためこの 二つの意味は一つの意味になれると思 われる。

エ.つける「就ける」 
上の記述を見ると、意味区別の長所と 短所がみられている。長所としては動 詞「つける」の意味が複数で取り上げ られている。短所としては、意味の区 別には不適切で表示されていない意味 もみられている。そのため、意味定義 の検討が必要と思われ、より適切な区 別の意味が表示することができるだろ う。

\section{鈴木（2000）}

鈴木（2000）は、「つく」という動 詞に見られる複数の意味のうち、相対 的にスキーマ的であると考えられるい くつかの顕著性の高い意味を抽出し それらの意味を相互に関係つけること である。また、抽出されたスキーマ的 意味をさらに細分化、より特定化し、

「つく」の用例を綱羅的に組み込みそ の関係の綱をより詳細にはりめぐらせ ていくことができれば、「つく」とい う動詞の意味のネットワーク構造をそ の細部に到るまであきらかにすること が目的である。

そのスキーマ的意味の抽出とその関 係付けは以下のように取り上げる。

1.1 〈ある対象物が〉〈別のある対象物に 〉〈物理的に〉〈触れ〉〈そこにとどまる〉
1.2 ある対象物が〉〈別のある対象物に 〉〈心理的に〉〈触れ〉〈そこにとどまる〉

1.3 ある対象物が〉〈別のある対象物に 〉とぞに〉く物理的に〉〈寄り〉〈そこにとど まる〉

1-4〈ある対象物が〉〈別のある対象物に 〉とそばに〉く理的に〉寄り〉くそこにとど まる〉

1.5 女る対象物が〉〈別のある対象物に 〉くそばに〉くある働きをするために〉く物理 的・心理的に〉〈寄り〉〈そこにとどまる〉

1.6 女る対象物が〉別のある対象物に 〉くそばに〉くある働きをするために〉く物理 的に〉触れ〉〈寄り〉くそこにとどまる〉

1. 7 PE〈ある対象物が〉〈別のある対象物に 〉〈物理的に〉触れ〉くそこにとどまり〉影 響を及ぼす>

1.8 〈る対象物が〉〈別のある対象物に 〉〈心理的に〉触れ〉くそこにとどまり〉影 響を及ぼす>

1.9 〈る対象物が〉〈別のある対象物へ 〉〈物理的に〉〈向かい〉〈そこにとどく〉

1.10 〈ある対象物が〉〈別のある対象物へ 〉くる働きをするために〉く理的に〉く向 かい〉くそこにとどき〉くとどまる〉 
2.1 〈る対象物に〉〈物理的に〉〈変化が 生じた結果〉〈別のある対象物が〉くそこに 現れる>

2.2 ある対象物に〉く心理的に〉変化 が生じた結果 $>\langle$ 別のある対象物が $〉 と$ こに現れる〉

3.1 ある対象物に〉く心理的に〉く現れ る〉く知覚される〉

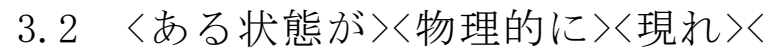
知覚される>

3.3 ある対象物に〉く心理的に〉現れ る〉〈物事が〉くおさまる

このように、スキーマ的意味の抽出と 関係付けの「つく」が見られて、ほぼ 妥当と思われるが、「つく」は「つけ る」の自動詞ということで、「つける」 の意味記述も必要と思われる。または、 この研究では多義構造が取り上げられ ていないことである。

\section{分析の結果}

本節では、基本義を記述し、別義を前 節に表示されている「つける」の意味 を踏まえて新たな定義を試み・または 一点ずつの別義を基本義と認知的な関 係を分析し、多義構造の図式化を試み る。

\section{「つける」の基本義}

「つける」の基本義は「ある物が 別のものにぴたりくつつく、離れられ ない状態」という定義である。

\section{「つける」の別義}

辞書記述に踏まえて「つける」の別 儀以下のようにまとめてみた。与える。

2）置く。

3）決める。

4）動かせる。

5) 書く。

6）添える。

7）切り込む。

8）浸す。

9）混ぜる。

10)点す。

11)塗る。

12) 監視する。

13)着る。

14）止める。

15) 慣用句の意味もある。

\section{「つける」の基本義と別儀の関連性}

以下に述べている関連性の分析で は認知言語学の定義に基づいて記述 されている。 
基本義：ある物が別のものにぴたりく つつく、離れられない状態

「つける」の基本義は以下の実例 から見られている。

（1）全体。3 同類。一駄 [いち だ＜wide>馬・牛の一頭につける 荷物。宿駅の馬につける荷物 の定めは、本馬一駄四十貫目、 荷

（中納言，2000：『基礎古文 書のことば』歴史・実著者不 明・柏書房）

（2）布団カバーにループを片手で 布団の上げ下ろしをするとき に、はしにループをつけると 作業が楽になる。《自助具ガ イド》たんすの引き手にヒモ をたんすの

（中納言，2000：『もう脳卒

中なんか恐くない』自然科 学・実著者不明・みずうみ書

「つける」の基本義は「ある物に 別の物をぴたりくつつく、つける こと、離れられない状態」である。 上の実例をみると、「馬・牛に荷 物をぴたりくっついて、つけるこ
と」、または「はしのループをぴ たりくつついて、つけること」が 分かっている。

これから、このような基本義を従 って、別義にどのような関連性が 用いられるかを分析を行う。

\section{別義 (1)：与える}

（3）感ずることができました。今、 日本で言われている「生きる 力」をつけるということは、 本当はこのようなことなので はないでしょうか。世界

（中納言，2000：『教師をめ ざす若者たち』社会科学・大 橋 功・プレジデント社) （4）タブをクリックする\#５［サ イト名」に 2 で削除したサイ トと同じ名前をつける\# 6 [O K K ］ボタンをクリックす る\#7［閉じる］ボタンをク リックする\#はみだしコラム\# 警告：

(中納言，2003：『はじめて のホームページビルダー7』 分類なし・西 真由・秀和シ ステム) 
上の実例では、「つける」は

「与える」という意味が用いられ ることが分かる。「ある物に別の 物をぴたりくっつく」という「つ ける」の基本義に基づいて、例で は（「身」に「生きる力」をつけ る）ということは「身に生きる力 を与える」または、（「サイト」 に「名前」をつける）ということ は「サイトに名前を与える」と思 われる。「ある物が別のものにぴ たりくっつく、離れられない状態」 と「与える」動作から見ると、 類似性が用いられるため、「つけ る」の別儀にメタファーの関連が 見られる。

\section{別義 (2)：置<}

（5）上のことはすべて三公に責任 を持たせて、功臣を行政官の 地位につけることはなかった から、諸将は、いずれも名誉 をまっとうして一生を終える こと （中納言，2000：『十八史略』歴 史・曾 先之・徳間書店）

（6）だという理由でペイオフの対 象からはずれることはありま せんが、優先順位をつけると
きに、満期がまだ先の預金か らカットされるわけです。こ こに注目！

(中納言，2002：『いちばんわか りやすいペイオフ 100 問 100 答』 社会科学・海江田 万里・アー ク出版）

上の実例では、「つける」は 「置く」という意味が用いられる ことが分かる。「ある物に別の物 をぴたりくっつく」という「つけ る」の基本義に基づいて、例では (「功臣」に「地位」につける) ということは「功臣に地位に置く」 または、（「ペイオフ」に「優先 順位」安らける)モということは 「ペイオフに優先順位を置く」と 思われる。「ある物が別のものに ぴたりくっつく、離れられない状 態」と「置く」 動作から見ると、 類似性が用いられるため、「つけ る」の別義にメタファーの関連が 見られる。

\section{別義 (3)：決める}

（7）見当たらないとされていまし た。そこで、解釈上の問題に 決着をつけるうえでも、成年 
後見人にならって、法人も成

年後見監督人になること

（中納言，2000：『Q\&A 成年後見 制度解説』社会科学 - 前田 裕 司・三省堂)

（8）と思う」「ㄱ」」あ、こ の男も色々と怪しげな解説を つけるものだ。奈々は呆れつ つも、話を戻す。

「中納言，2000：あと一辻名さ んの （『QED』文学・高田 崇 史・講談社)

上の実例では、「つける」は 「決める」という意味が用いられ ることが分かる。「ある物に別の 物をぴたりくっつく」という「つ ける」の基本義に基づいて、例で は（「問題」に「決着」をつける） ということは「問題に対しての決 着を決める」または、（「この男 が」が「解説」をつける）という ことは「この男解説をきめる」と 思われる。「決める」の意味では、 「つける」だけでなく、動作から 見ると、「決着」「解説」を「問 題」「この男」につければ、（決 着と解決決められる）というわけ である。そのため、これらに「つ
ける」の別義に 近接関係がある ため、メトニミーの関連であるこ と思われる。

\section{別義 (4)：働かせる}

（9）を行い、本人にも意見を述べ る機会を与えて、最終的に後 見人をつけるべきかどうかが 決められます。鑑定を行うに 当たっては、鑑定費用を

（中納言，2001：『現場の成年 後見 Q\&A』社会科学・池原 毅 和・有斐閣)

（10）する準備を整えておけばよい。 そう考えて呂布は兵を城門の 警備につける。だが、兵が 警備につくより早く、軍が帰 城したどさくさに

（中納言，2001：『三国演義』 文学・安能 務・講談社)

上の実例では、「つける」は 「働かせる」という意味が用い られることが分かる。「ある物 に別の物をぴたりくっつく」と いう「つける」の基本義に基づ いて、例では（「ある機関」に 「後見人」をつける）というこ とは「ある機関で後見人を働か 
せる」または、（「城門」に

「警備」をつける）ということ

は「城で警備を働かせる」と思 われる。この分析では、「後見

人」「警備」に「役わり」をつ

け、「ある機関」「城門」では

たらかせてもらうと考えられる。

つまり、「つける」は「方法」、

「役わりを与える」は「目的」

となると、これらの関連はメト

ニミーである。

\section{別義 (5)：書<}

（11）自分自身の実践の正当性を疑 問視しないことである。彼は 日記をつけることを時的に、 さらには決定的に止めるかも

しれない。しかし、だ

(中納言，2000：『友愛の歴 史社会学』社会科学・葛山

泰央・岩波書店）

（12）確立することです。 先に紹 介した自分のための「エネル ギーノート」をつけるのも一 つの方法です。「私は語学 ができないから」「時間

(中納言，2002：『女の運命 を動かす 100 の方法』哲学・ 浅野 裕子・三笠書房)
上の実例では、「つける」は

「書く」という意味が用いられる ことが分かる。「ある物に別の物 をぴたりくつつく」という「つけ る」の基本義に基づいて、例では （「日記」に「書くもの」をつけ る）ということは「日記に書くも のを近づけさせて、書く」または、 （「エネルギーノート」に「書く もの」をつける）ということは 「エネルギーノートに書くもを近 づけさせて、書く」らら考えられる。 「書く」動作から見ると、「つ ける」は「方法」、「書く」は 「目的」、いわゆる、この別儀で は、怕メトミーの関連が見られる。

\section{別義(6)：添える}

（13）を使用しても一日に一回、一 杯だけです。毎食みそ汁を己 けるとどうしても塩分をとり すぎになります。高血圧食で すとその程度

（中納言，2000：『高齢者の介 護とスキンケア』自然科学・ 伊崎 誠一・丸善)

（14） 3 : 塩 1 の割合で混ぜる。肉、 魚、野菜の揚げもの、春巻き 
などにつけるとおしいので、 常備すると何かと重宝。

椒

塩八頭は、普通

（中納言，2000：『アジアのお

母さんの味』技術・工学・分

担不明・日本放送出版協会）

上の実例では、「つける」は

「添える」という意味が用いられ

ることが分かる。「ある物に別の

物をぴたりくっつく」という「つ

ける」の基本義に基づいて、例で

は（「食べ物」に「みそ汁」をつ

ける）ということは「食べ物にみ

そ汁を添える」または、（「春巻

き」に「肉、魚、野菜の揚げ物」

をつける）ということは「春巻き

に肉、魚、野菜の揚げ物を添える」

と考えられる。「ある物が別のも

のにぴたりくっつく、離れられな

い状態」と「添える」動作から

見ると、類似性が用いられるため、

「つける」の別義にメタファーの

関連が見られる。

\section{別義 (7)：切り込む}

（15）考えていただければわかるよ うに非常に不愉快な、しかも 感染や尿道に傷をつける可能
性のある方法です。最近はこ の副作用の予防のために、メ スナと

（中納言，2000：『むしばまれ る医療』自然科学・秋山 秀

樹・日本評論社)

（16）はないの?」「お母さんが 絶対だめだって。体に傷をつ けるの良くないから。西洋医 学のやり方は、極端すぎるし 衴」彼女の

(中納言，2003：『中国洗面器 ご飯』社会科学・一条さゆ り・講談社)

\section{上の実例では、「つける」は}

「切り込む」という意味が用いら れることが分かる。「ある物に別 の物をぴたりくつつく」という 「つける」の基本義に基づいて、 例では（「尿道」に「傷」につけ る）ということは「尿道に傷を切 り込む」または、（「体」に「傷」 をつける）ということは「体に傷 を切り込む」と思われる。「ある 物が別のものにぴたりくっつく、 離れられない状態」は「全体」を 表す動作だが、「切り込む」は 「部分」表す動作を示していいる。 
そのため、「つける」の別義にシ

ネクドキの関連が見られる。

\section{別義 (8)：浸す}

（17）ます。 酢水は、水 1 カップ に酢大さじ 2 の見当。長芋を 酢水につけるのは、そのまま だと粘りが出て扱いにくいた めです。器 3 点

（中納言，2000：『夏おかずレ シピ 150』技術・工学・小川

$$
\text { 圭子・グラフ社) }
$$

（18）網目の内側や隅のほうまでし っかり洗い、よく洗い流す塩 素系漂白鼡に 1 時間つける。

これより短い時間だと、カビ の胞子が死滅しないこともあ るので

（中納言，2000：『最強のお掃 除テキスト』技術・工学・城

$$
\text { 石 眞紀子・扶桑社) }
$$

上の実例では、「つける」は

「浸す」という意味が用いられる ことが分かる。「ある物に別の物 をぴたりくっつく」という「つけ る」の基本義に基づいて、例では

(「長芋」に「酢水」をつける) ということは「長芋を酢水に浸す」
または、（「洗濯物」に「塩素系 漂白剤」をつける）ということは 「洗濯物を塩素系漂白剤に浸す」 と思われる。「ある物が別のもの にぴたりくっつく、離れられない 状態」と「浸寸」動作から見る と、類似性が用いられるため、 「つける」の別義にメタファーの 関連が見られる。

\section{別義 (9)：混ぜる}

（19）肉に薄力粉をまぶし、溶きほ ぐした卵液をくぐらせ、香草 パン粉をしっかり つける。 3 フライパンにオリーブ油 とバターを熱して、油をかけ ながら焼く。 （中納言，2000：『宇土巻子の ハーブクッキング』技術・工 学・宇土 巻子・講談社 （20）を作る。椎茸は布巾で拭いて 石づきを切り、笠裏に薄く小 麦粉をつける。芝海老は背ワ タを取って殼をむき、庖丁で 吒いてからあたり鉢であたり、 (中納言，2001：『居酒屋の人 気の和風料理』技術 - 工学 • 志の島 忠・旭屋出版） 
上の実例では、「つける」は

「混ぜる」という意味が用いられ ることが分かる。「ある物に別の 物をぴたりくっつく」という「つ ける」の基本義に基づいて、例で は（「生地」に「パン粉」をつけ る）ということは「生地にパン粉 を入れて混ぜる」または、（「椎 茸」に「小麦粉」をつける）とい うことは「椎茸に小麦粉を入れて 混ぜる」と思われる。「ある物が 別のものにぴたりくつつく、離れ られない状態」と「混ぜる」動 作から見ると、類似性が用いられ るため、「つける」の別義にメタ ファーの関連が見られる。

\section{別義 (10)：点す}

（21）から、またソープに行ってし まった。そこを出てから、部 屋の明かりをつけるのはまず いだろう、とふと考えて、法 外に高いのはわかっているの に

(中納言，2000：『フリージア』 文学・東 直己・角川春樹事 務所）

（22）に一回は目をさまして、悪口 雑言をならべたあげく、タバ
コに火をつける。膀胱の病気 持ちの男は、一晚に六回くら い起きて、大きな音 (中納言, 2001：『パリ・ロン ドン放浪記』文学・ジョー ジ・オーウェル・岩波書店）

上の実例では、「つける」は 「点す」という意味が用いられる ことが分かる。「ある物に別の物 をぴたりくっつく」という「つけ る」の基本義に基づいて、例では （「明かり」をつける）というこ とは「明かりに電気を点す」また は、(「タバコ」に「火」をつけ る）ということは「タバコに火を 点す」と思われる。「ある物が別 のものにぴたりくっつく、離れら れない状態」と「点す」動作か ら見ると、類似性が用いられるた め、「つける」の別義にメタファ 一の関連が見られる。

別儀（11）: 塗る

（23）カサカサになってしまうので すがそれを防ぐ方法はありま せんか?ファンデーションを つけるとどうしても目立って 
しまうので…私は、オルビス をつかっています

(中納言，2005：『Yahoo! 知恵 袋』健康、美容とファッショ ン/コスメ、美容/コスメ、美 容・Yahoo!)

（24）性はアルビオンですね。ただ アルビオンは乳液を先につけ て、化粧水を次につけるとう 特質なものですので乳液をつ けなきやあまり効果がないみ たいです。

(中納言, 2005：『Yahoo! 知恵 袋』健康、美容とファッショ ン/コスメ、美容/コスメ、化 粧品・Yahoo!）

\section{上の実例では、「つける」は}

「塗る」という意味が用いられる ことが分かる。「ある物に別の物 をぴたりくつつく」という「つけ る」の基本義に基づいて、例では (「顔」に「ファンデーション」 をつける）ということは「顔にフ アンデーションんを塗る」または、

（「顔」に「乳液」をつける）と いうことは「顔に乳液を塗る」と 思われる。「ある物が別のものに
ぴたりくっつく、離れられない状 態」と「塗る」動作から見ると、 類似性が用いられるため、「つけ る」の別義にメタファーの関連が 見られる。

\section{別義 (12)：監視する}

（25）あなた一人だけで行動はさせ ません。\#必ず誰か警察官を あなたにつけるよう、こちら から要求します。\#しかも、 あなたの周りは、何十もの捜 査

（中納言，2001：『爆弾魔』文 学・大石 直紀 $\cdot$ 光文社)

（26）兇悪事件に匹敵する態勢で捜 査に乗り出すだろう。\#娘に 二十四時間の警護をつける一 方、相手の男性の身辺を徹底 的に調べ上げ、多少やましい 点でもみつかったら (中納言，2001：『日本封印』 文学・杉山 隆男・小学館)

上の実例では、「つける」は 「監視する」という意味が用いら れることが分かる。「ある物に別 の物をぴたりくつつく」という 
「つける」の基本義に基づいて、

例では（「あなた」に「警察官」 につける）ということは「あなた を警察官に監視する」または、

（「娘」に「警護」をつける）と いうことは「娘を警護に監視する」 と思われる。「ある物が別のもの にぴたりくっつく、離れられない 状態」と「監視する」 動作から 見ると、類似性が用いられるため、 「つける」の別義にメタファーの 関連が見られる。

\section{別義 (15)：着る}

（27）機長は制服を身に着けた。 （小泉，1996：326）

上の実例では、「つける」は「着 る」という意味が用いられること が分かる。「ある物に別の物をぴ たりくっつく」という「つける」 の基本義に基づいて、例では

(「機長」に「制服」を「身」に つける）ということは「機長の体 に征服を着る」と思われる。「着 る」動作から見ると、つけるだ けではなく、「つける」は「全体」
の動作、「着る」は「部分」の動 作と考えられるため、この別義に シネクドキの関連が見られる。

\section{別義 (14)：止める}

（28）運転集は車を駅の正面に着け た。

（小泉，1996：326）

（29）船頭は船を岸に着けた。

（小泉，1996：326）

「止める」という意味が用いられ ることが分かる。「ある物に別の 物をぴたりくっつく」という「つ ける」の基本義に基づいて、例で は（「駅の正面」に「車」をつけ る）ということは「車は駅の正面 に止める」または、（「岸」に 「船」をつける）ということは 「船は岸に止める」と思われる。 「止める」 動作から見ると、あ るものをつけて、その後とめるこ と。ここでは、全体的の意味から、 部分的の意味を表しているため、 シネクドキの関連が見られる。 
上記に記述した関連性は、以下の

欄にまとめる。

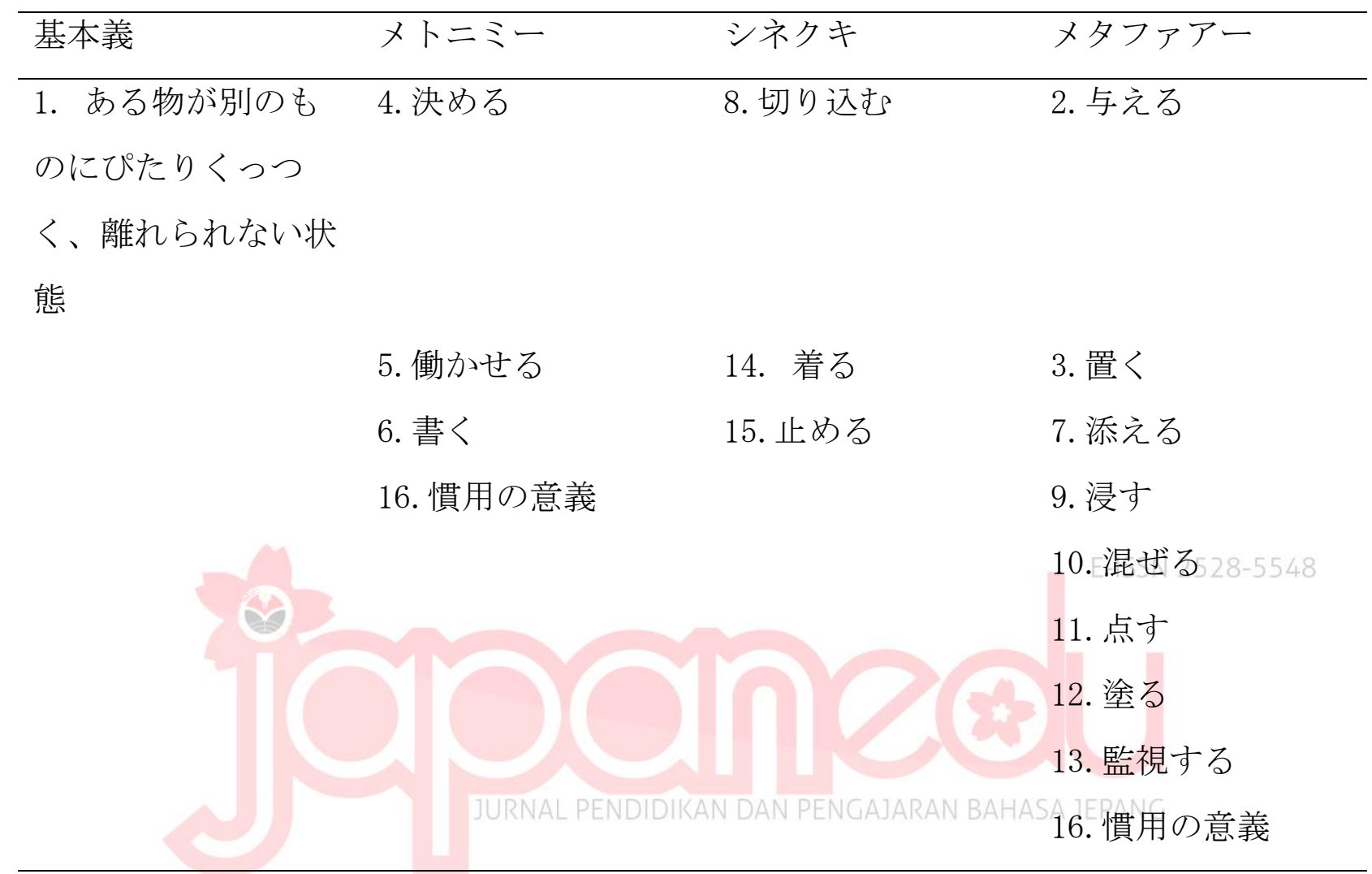

終わりに

これまでの考察で明らかになった 「つける」の意味は、以下の通りで ある。

・「つける」の基本義は「ある 物が別のものにぴたりくっつ

く」、離れられない状態」と

いう定義である。

・「つける」の別義は

(1)与える

(2) 置く
(3) 決める

（4）働かせる

(5) 書<

(6) 添える

(7) 切り込む

(8) 浸す

(9)混ぜる

（10）点す

(11) 塗る

（12）監視する

(13) 着る 
（14）止める

「つける」の基本義と別義の関連性は、

図式化すると以下のようになる。
(4) (5) (6) (16)
（1）基本義
(2)
(3) (7)
(9) (10)
(11)
メトニミー
メタファー!
シネ!クドキ
(13) (16)

(8) (14) (15)

1.ある物が別のものにぴたりく つつく、離れられない状態

2. 与える

3. 置

4. 決める

5. 働かせる

6. 書<

7. 添える

8. 切り込む

上記のの図式を説明すると、(1)「ある物 が別のものにぴたりくつつく、離れられ ない状態」は基本義で、または、メタフ アーとしての別儀は(2)「与える」(3)「置 く」(7)「添える」 (9)「浸す」(10「混ぜる」 (11)「点す」(12)「塗る」 (13)「監視する」慣 用の意義」、それにメトニミーとしての
9. 浸す

10. 混ぜる

11. 点す

12. 塗る

13. 監視する

14. 着る

15. 止める

16. 慣用句の意義

別儀は(4)「決める」(5)「働かせる」(6) 「書く」(16)「慣用句の意義」、最後はシ ネクドキとしての別儀は8「切り込む」 (14)「着る」(15)「止める」ということがわ かった。 


\section{参考文献}

[1]秋元美晴 （2010）『日本語教育能力 検定試験に合するための語彙 12 』 アルク

［2］小泉保 （1989）『日本語基本動詞 用法辞典』大修館書店

[3]鈴木智美 （2000）『多義語「ツク」 （付・着・就・即・憑・点）の意味 分析一そのスキーマ的意味の抽出と 関係付け一』留学生日本語教育セン ター論集 $27: 79^{\sim} 92 ， 2001$

[4] 野間佐和子（1989）『日本語大辞典 第二版、』講談社

[5] Chaer, Abdul (2012). Linguistik Umum. Jakarta: Rineka Citpa

[6] Kamus Besar Bahasa Indonesia (2008) Jakarta: PT Gramedia Pustaka Utama

[7] Matsuura, Kenji (2005) Kamus Jepang - Indonesia. Jakarta: PT Gramedia Pustaka Utama

[8] Moleong, Lexy (2010) Metodologi Penelitian Kualitatif. Bandung: PT Remaja Rosdakarya

[9] Sudjianto \& Dahidi, Ahmad (2009) Pengantar Linguistik Bahasa Jepang. Bekasi Timur: Kesaint Blanc

[10] Sutedi, Dedi (2011, terbitan ke-2), Penelitian Pendidikan Bahasa Jepang, Bandung: Humaniora
[11] (2011), Dasar-Dasar

Linguistik Bahasa Jepang, Bandung: Humaniora (2001), Analisis makna verba Agaru dan Noboru, Jepang Tengah: FUSII Nomor 8 (2015), Kalimat Pasif

Bahasa Jepang. Bandung: Humaniora

[14] Homepage Korpus: http:// https://chunagon.ninjal.ac.jp (chunagon-privateusers) 